\title{
PENGARUH PROFITABILITAS, LEVERGE, DAN UKURAN PERUSAHAAN TERHADAP HARGA SAHAM ANTARA INDONESIA DAN MALAYSIA
}

\author{
Putri Ayu Ifani \\ Fakultas Ekonomi Dan Bisnis Universitas Pancasila \\ Lailah Fujianti \\ Fakultas Ekonomi Dan Bisnis Universitas Pancasila \\ email : shintabudiastuti@univpancasila.ac.id \\ Shinta Budi Astuti \\ Fakultas Ekonomi Dan Bisnis Universitas Pancasila \\ email : lailahfujianti@gmail.com
}

\begin{abstract}
Abstrak
Penelitian ini bertujuan untuk mengetahui dan menguji secara empiris pengaruh dan perbedaan pengaruh Return On Assets, Debt to Equity Ratio, dan ukuran perusahaan terhadap harga saham perusahaan manufaktur yang terdaftar di Bursa Efek Indonesia dan perusahaan manufaktur yang terdaftar di Bursa Malaysia pada tahun 2016. Sampel yang digunakan dalam penelitian ini masing-masing sebanyak 60 perusahaan manufaktur. Sampel diperoleh menggunakan metode random sampling dan uji Smith-Satterthwait. Penelitian ini dilakukan dengan menggunakan analisis regresi linear berganda. Penelitian ini memiliki hasil Return On Assets dan ukuran perusahaan, berpengaruh positif terhadap harga saham di Bursa Efek Indonesia dan Malaysia sedangkan Debt to Equity Ratio tidak berpengaruh terhadap harga saham Indonesia dan Malaysia dan Return On Asset dan ukuran perusahaan tidak memiliki perbedaan signifikan terhadap harga saham Indonesia dan Malaysia.
\end{abstract}

Kata kunci : Return On Assets, Earnings Per Share, Debt to Equity Ratio, Ukuran Perusahaan, Harga Saham.

\begin{abstract}
The study aims to discover and examine the effects and differences Return On Assets, Debt to Euity ratio, and company size on stock price of manufacturing companies listed on Indonesia Stock Exchange as well as listed on Malaysia Stock Exchange in 2016. Furthrmore, this reseach's sample of 60 companies of each stock exchange and obtained by implementing random sampling method. This research applies multipliesd linear regression method and and Smith-Satterthwait test to analyse the sample. In conclusion, Return on Asset and company size have positive impact on the shareprice of Indonesia and Malaysia Stock Exchange. However, Debt to Equity Ratio does not influence the stock price as well as Return On Asset and Value of company are not significantly difference on the Stock Price of manufacturing company in Indonesia and Malaysia.
\end{abstract}

Keywords : Return On Assets, Earnings Per Share, Debt to Equity Ratio, Company size, Stock Price.

\section{PENDAHULUAN}

Semakin maju perekonomian suatu negara, maka akan semakin besar peran pasar modal yang diikuti dengan mengecilnya peran perbankan komersial dalam memobilisasi mereka ke arah sektor produktif. Setiap negara memiliki pasar modal yang memiliki kebijakan berbeda. Perkembangan investasi pasar modal di Indonesia mulai berkembang dengan kemajuan yang 
gemilang pada tahun 2017 dengan pertumbuhan Indeks Harga Saham Gabungan (IHSG) mencapai 19,99 persen.

Saham di Indonesia tidak terlalu mahal dan murah dibandingkan Filipina. Indonesia sebagai negara berkembang mampu memperlihatkan prestasi yang menarik dalam dunia pasar modal. Perbedaan iklim, kebijakan, geografis, dan berbagai faktor di suatu negara memiliki dampak yang berbeda di setiap negara. Malaysia adalah negara yang secara geografis memiliki geografis yang dekat dengan Indonesia, perkembangan perekonomian di Malaysia pun lebih maju dibandingkan Indonesia.

Menurut Subhan (2016) "Pasar modal memiliki peran besar dalam perekonomian suatu negara karena perkembangan suatu negara dapat diukur salah satunya dengan melihat perkembangan pasar modal dan industri surat berharga di negara tersebut. Pasar modal merupakan pertemuan antara pihak yang memiliki kelebihan dana dengan pihak yang membutuhkan dana dengan cara memperjualbelikan sekuritas". Berinvestasi dalam bentuk saham memiliki risiko yang lebih besar dibandingkan dengan berinvetasi di sektor rill dalam bentuk tanah, emas, dan properti. Namun, risiko yang besar tersebut dapat dihindari dan diminimalisir dengan cara menganalisis harga saham perusahaan yang terdapat di pasar modal.

Menurut Gitaya (2014), "Terdapat dua pendekatan dalam analisis harga saham yaitu dengan pendekatan analisis teknikal dan analisis fundamental". Menurut Fahriyah (2015), "Analisa fundamental merupakan analisis untuk memproyeksi harga saham dengan mengestiminasi nilai faktor-faktor fundamental yang memengaruhi harga saham pada masa yang akan datang dan menerapkan hubugan variabel tersebut sehingga diperoleh taksiran harga saham". Untuk melakukan analisis fundamental, diperlukan data atau informasi. Pada umumnya, investor dan calon investor mengunakan data keuangan dalam melakukan analisis fundamental dalam pengambilan keputusan bagi investor untuk berinvestasi . Data keuangan tersebut dapat berupa rasio kinerja keuangan. Menurut Meythi, et al (2013) "Rasio keuangan terdiri dari rasio likuiditas, rasio aktivitas, rasio solvabilitas, dan rasio profitabilitas".

Profitabilitas adalah indikator yang digunakan untuk mengukur efektivitas manajemen secara keseluruhan yang ditujukan oleh besar kecilnya tingkat keuntungan yang diperoleh dalam hubungannya dengan penjualan maupun investasi. Semakin baik rasio profitabilitas, maka semakin baik menggambarkan kemampuan tingginya perolehan keuntungan perusahaan (Lia dalam Irham, 2015). Rasio profitabilitas yang digunakan pada penelitian ini adalah Return On Assets (ROA). Rasio ini digunakan untuk mengukur kemampuan perusahaan menghasilkan laba berdasarkan modal saham tertentu dan merupakan ukuran profitabilitas dari sudut pandang pemegang saham (Setyorini, 2016).

Leverge adalah rasio yang menggambarkan hubungan antara hutang perusahaan terhadap modal, rasio ini dapat melihat seberapa jauh perusahaan dibiayai oleh hutang atau pihak luar dengan kemampuan perusahaan yang digambarkan modal". Leverge memiliki beberapa rasio, salah satu rasio yang digunakan yaitu debt to equity ratio (DER). Menurut Pebri (2014) "DER akan memengaruhi harga saham karena rasio ini digunakan untuk mengukur kemampuan perusahaan dalam menutupi sebagian atau seluruh hutang-hutangnya, baik jangka panjang maupun jangka pendek yangg berasal dari modal sendiri".

Ukuran perusahaan merupakan salah satu faktor bagi para investor dalam melihat performa perusahaan. Ukuran perusahan dapat dilihat dalam total aktiva dan total penjualan bersih. Semakin besar total aktiva dan total penjualan bersih, maka akan semakin besar ukuran suatu perusahaan. Berdasarkan teori dan fenomena yang telah diuraikan di atas, maka penelitian ini diberi judul "PENGARUH PROFITABILITAS, UKURAN PERUSAHAN DAN LEVERG TERHADAP HARGA SAHAM ANTARA INDONESIA DAN MALAYSIA”.

\section{TINJAUAN PUSTAKA \\ Pengertian Saham}

Menurut Darmadji dan Fakhruddin (2012:5), "Saham (stock) merupakan tanda penyertaan atau pemilikan seseorang atau badan dalam suatu perusahaan atau perseroan terbatas. Saham berwujud selembar kertas yang menerangkan bahwa pemilik kertas tersebut adalah pemilik perusahaan yang menerbitkan surat berharga tersebut". Firmansyah (2017), mengemukakan saham merupakan suatu instrumen pasar modal yang digunakan sebagai bukti kepemilikan pemegang 
saham atas perusahaan. Secara sederhana saham dapat diartikan sebagai sertifikat yang menunjukan bukti kepemilikan terhadap perusahan dan pemegang saham memiliki hak atas penghasilan dan aset perusahaan. (Wanggari, 2015).

\section{Harga Saham}

Menurut Jogiyanto H.M (2015:8), harga saham adalah harga saham yang terjadi di pasar bursa pada saat tertentu yang akan ditentukan oleh pelaku pasa pada saat tertentu yang ditentukan oleh pelaku pada dan ditentukan oleh permintaan dan penawaran saham yang bersangkutan di pasar modal". Widoatmojo (2012: 91), menyatakan bahwa harga saham dapat dibedakan menjadi tiga yaitu harga nominal, harga perdana, dan harga pasar.

\section{Analisis Harga Saham}

Pada umumnya dalam menganalisa harga suatu saham dapat menggunakan dua metode yaitu analisis fundamental dan analisis teknikal. Darmadji dan Fakhruddin (2012:149), menyatakan bahwa analisis fundamental merupakan salah satu cara untuk melakukan penilaian saham dengan mempelajari atau mangamati berbagai indikator yang terkait dengan kondisi makro dan kondisi industri suatu perusahaan hingga berbagai indikator keuangan dan manajemen perusahaan. Darmadji dan Fakhruddin (2012:149), juga menyatakan bahwa analisis teknikal merupakan salah satu metode yang digunakan untuk penilaian saham, di mana dengan metode ini para analis melakukan evaluasi saham berbasis pada data-data statistik yang dihasilkan dari aktivitas perdagangan saham, seperti harga saham dan volume transaksi.

\section{Karakteristik Perusahaan}

Karakteristik perusahaan merupakan kualitas yang terdapat dalam perusahaan. Subhair (2013), mengatakan karakteristik perusahaan merupakan ciri khas atau sifat yang melekat dalam suatu usaha yang dapat dilihat dari beberapa segi, diantaranya jenis usaha atau industri, struktur kepemilikan, tingkat likuiditas, tingkat profitabilitas, ukuran perusahaan. Purnama (2018) juga menyatakan bahwa karakteristik perusahaan merupakan sifat yang melekat pada entitas usaha yang dapat dilihat dari sudut pandang, diantaranya jenis usaha atau industri, struktur kepemilikan, tingkat likuiditas, tingkat profitabilitas, dan ukuran perusahaan. Karakteristik perusahaan sendiri diproksikan dengan ukuran perusahaan, profitabilitas, leverage, umur perusahaan, kepemilikan manajerial, pertumbuhan, kebijakan deviden dan likuiditas (B. Mahardika dan A. Roosmawarni, 2016).

\section{Return On Assets (ROA)}

Menurut Harahap (2011:304), menyatakan Return On Assets (ROA) menggambarkan perputaran aktiva diukur dari volume penjualan. Return On Assets (ROA) adalah pengukuran kinerja keuangan yang diinvestasikan dalam keseluruhan aktiva yang dimiliki untuk menghasilkan laba. Return On Asset mengambarkan sejauh mana kemampuan aset yang dimiliki perusahaan dapa menghasilkan laba, maka Return On Assets merupakan pengukuran kinerja keuangan yang menggambarkan sejauh mana kemampuan seluruh aset yang dimiliki oleh perusahaaan dapat menghasilkan laba.

$$
\text { Return On Assets }=\frac{\text { Earning After Tax }}{\text { Total Assets }}
$$

\section{Debt to Equity Ratio}

Hery (dalam Wangarry, Poputra dan Runtu, 2015), menyatakan bahwa Debt to Equity Ratio (DER) merupakan rasio yang digunakan untuk mengukur besarnya proporsi hutang terhadap modal. Rasio ini dihitung sebagai hasil bagi antara total hutang dengan modal. Rusdin (2009:142), menyatakan bahwa Debt to Equity Ratio menunjukkan struktur pemodalan emiten jika dibandingkan dengan kewajiban. Selanjutnya, menurut Riyanto (2010:333) Debt to Equity Ratio membandingkan total hutang dengan jumlah modal sendiri. Kasmir (2012:155) merumuskan perhitungan Debt to Equity Ratio sebagai berikut: 


$$
\text { Debt to Equity Ratio }=\frac{\text { Total Debt }}{\text { Total Equity }}
$$

\section{Ukuran Perusahaan}

B. Mahardika dan A. Roosmawarni (2016), mengungkapkan ukuran perusahaan (Size) merupakan karakteristik perusahaan yang menentukan nilai perusahaan dan salah satu hal yang dipertimbangkan perusahaan dalam meningkatkan nilai perusahaan. Ukuran perusahaan adalah suatu skala dimana dapat diklasifikasikan besar kecilnya perusahaan menurut berbagai cara antara lain dengan total aktiva, log size, harga pasar saham, dan lain-lain (Mirawati, 2014).

\section{Ukuran Perusahaan $=$ Ln Total Aset}

\section{Pengaruh Return On Asset Terhadap Harga Saham}

Hasil penelitian Gitaya (2014) dan Rizky (2017) memperoleh hasil Return On Assets berpengaruh terhadap harga saham. Sedangkan hasil penelitian Setyorini (2016) memperoleh hasil Return On Assets tidak berpengaruh terhadap harga saham, dengan demikian hipotesis penelitian adalah:

$\mathrm{H}_{1}=$ Return On Assets berpengaruh terhadap harga saham di Indonesia

$\mathrm{H}_{2}=$ Return On Assets berpengaruh terhadap harga saham di Malaysia

$\mathrm{H}_{3}=$ Ada perbedaan pengaruh Return On Assets terhadap harga saham di Indonesia dan Malaysia

\section{Pengaruh Debt To Equity Terhadap Harga Saham}

Hasil Penelitian Fahriyah (2015) dan Wangarry, et al (2015) memperoleh hasil Debt to Equity berpengaruh terhadap harga saham, sedangkan hasil R.K. Kumaidi dan N. Asandimitra (2017) memperoleh Debt to Equity tidak berpengaruh terhadap harga saham, dengan demikian hipotesis penelitian adalah:
$\mathrm{H}_{4}=\quad$ Debt to Equity berpengaruh terhadap harga saham di Indonesia
$\mathrm{H}_{5}=\quad$ Debt to Equity berpengaruh terhadap harga saham di Malaysia
$\mathrm{H}_{6}=\quad$ Ada perbedaan pengaruh Debt to Equity terhadap harga saham di Indonesia dan Malaysia

\section{Pengaruh Ukuran Perusahaan Terhadap Harga Saham}

Hasil Penelitian Ainul (2018) memperoleh hasil ukuran perusahaan berpengaruh secara signifikan terhadap harga saham, sedangkan Istianah (2018) memperoleh ukuran perusahaan berpengaruh, namun tidak signifikan terhadap harga saham, dengan demikian hipotesis penelitian adalah:
$\mathrm{H}_{7}=\quad$ Ukuran Perusahaan berpengaruh terhadap harga saham di Indonesia
$\mathrm{H}_{8}=\quad$ Ukuran Perusahaan berpengaruh terhadap harga saham di Malaysia
$\mathrm{H}_{9}=\quad$ Ada perbedaan pengaruh Ukuran Perusahaan terhadap harga saham di Indonesia dan Malaysia

\section{METODE PENELITIAN}

Jenis data dalam penelitian ini adalah data sekunder. Data sekunder yaitu data penelitian yang dikumpulkan dari sumber-sumber tercetak yang telah dikumpulkan oleh pihak lain sebelumnya berupa buku, laporan perusahaan, jurnal, internet, dan sebagainya. Sumber data Indonesia yang digunakan berasal dari www.idx.co.id, pojok BEI (Bursa Efek Indonesia) Universitas Pancasila. Sumber data Malaysia yang digunakan berasal dari www.bursamalaysia.com dan www.investing.com. Berdasarkan teknik simple random sampling, data yang digunakan dalam penelitian ini terdiri dari 60 Perusahaan dengan periode pengamatan bagi variabel dependen pada tahun 2016 dan variabel independen pada Maret 2017. 
Tabel 1

Operasional Variabel

\begin{tabular}{|c|c|c|c|c|}
\hline \multicolumn{5}{|l|}{ W } \\
\hline Variabel & No & Sub Variabel & Indikator & Skala \\
\hline $\mathrm{Y}$ & 1 & Harga Saham & $\begin{array}{l}\text { Harga saham saat penutupan } \\
\text { akhir periode laporan }\end{array}$ & Nominal \\
\hline \multirow{5}{*}{$\mathrm{X}$} & \multirow{2}{*}{2} & \multirow{2}{*}{$\begin{array}{l}\text { Return On Asset } \\
\text { (ROA) }\end{array}$} & Earning After Tax & \multirow[b]{2}{*}{ Rasio } \\
\hline & & & Total Assets & \\
\hline & \multirow{2}{*}{3} & \multirow{2}{*}{$\begin{array}{l}\text { Debt To equity } \\
\text { (DER) }\end{array}$} & Total Debt & \multirow{2}{*}{ Rasio } \\
\hline & & & Total Equity & \\
\hline & 4 & $\begin{array}{l}\text { Ukuran Perusahaan } \\
\text { (LTA) }\end{array}$ & Ln Total Aset & Rasio \\
\hline
\end{tabular}

\section{Uji Asumsi Klasik}

\section{Uji Normalitas}

Model regresi dikatakan baik jika memiliki residual yang terdistribusi secara normal atau mendekati normal. Uji Normalitas dapat dilakukan dengan cara Normal Probality Plot dan Kolmogorov Smirnov. Pada penelitian ini, uji normalitas menggunakan Kolmogorov Smirnov. Menurut Uji Kolmogorov Smirnov, data normal bila probilitas Asymp.sig(2-tailed) lebih dari 0,05

\section{Uji Multikolineritas}

Menurut Umar (2011:177), "Multikolinearitas adalah untuk mengetahui apakah pada model regresi ditemukan adanya korelasi antar variabel independen". Untuk menganalisis uji multikolinearitas dapat dilakukan dengan cara mengamati nilai dari Varians Inflation Factor (VIF). Menurut Jakaria (2015:159) "Beberapa ahli berpendapat bahwa nilai toleransi kurang dari 0,1 atau VIF lebih besar dari 10 menunjukkan multikolinearitas signifikan, sementara itu para ahli lainnya menegaskan bahwa besarnya $\mathrm{R}^{2}$ model dianggap mengindikasikan adanya multikolinearitas".

\section{Uji Heteroskedastisitas}

Menurut Umar (2011:179) "Heteroskedastisitas adalah dilakukan untuk mengetahui apakah dalam sebuah model regresi terjadi ketidaksamaan varians dari residual suatu pengamatan ke pengamatan lain". Untuk menganalisis uji heteroskedastisitas dilakukan dengan cara mengamati pola tertentu pada grafik Scatterplot antar SRESID dan ZPRED. Jakaria (2015:161) menyatakan bahwa setelah data diuji dan terlihat bahwa titik-titik menyebar secara acak serta tidak membentuk pola tertentu atau tidak teratur hal ini mengindikasikan tidak terjadi heterokedastisitas pada model regresi sehingga model regresi layak dipakai.

\section{Uji Autokolerasi}

Uji autokorelasi merupakan pengujian di mana variabel dependen tidak berkorelasi dengan nilai variabel itu sendiri, baik nilai periode sebelumnya maupun nilai periode sesudahnya. Menurut Duwi Priyatno (2012:172), Autokorelasi adalah keadaan di mana pada model regresi ada korelasi antara residual pada periode tertentu $\mathrm{t}$ dengan residual pada periode sebelumnya $(\mathrm{t}-1)$, model regresi yang baik adalah yang tidak terdapat masalah autokorelasi. Penelitian ini uji autokorelasi tidak diperlukan karena uji autokolerasi hanya dilakukan pada data time series (runtut waktu) dan tidak perlu dilakukan pada data cross section seperti pada penelitian ini yang pengukuran semua variabel dilakukan secara serempak pada saat yang bersamaan

\section{Uji Hipotesis}

Uji Koefisiens Determinasi $\left(\mathbf{R}^{2)}\right.$

Koefisien determinasi $\left(\mathrm{R}^{2}\right)$ digunakan untuk mengukur seberapa jauh kemampuan variabel-variabel independen dalam menjelaskan variabel dependen. Nilai $\mathrm{R}^{2}$ yang kecil menunjukkan bahwa kemampuan variabel independen terbatas dalam menjelaskan variabel dependen. Sedangkan semakin dekat $\mathrm{R}^{2}$ mendekati 1, maka menunjukkan bahwa variabel independen memberikan hampir semua informasi yang dibutuhkan untuk memprediksi variabel dependen. 


\section{Uji Silmutan (Uji F)}

Menurut Ghozali (2012: 98) "Uji Statistik F pada dasarnya menunjukkan apakah semua variabel independen atau variabel bebas yang dimasukkan dalam model mempunyai pengaruh secara bersama-sama terhadap variabel dependen atau variabel terikat. Bila probabilitas $\mathrm{F}_{\text {hitung }}<$ 0.05 , menandakan bahwa secara simultan variabel bebas mempunyai pengaruh yang signifikan terhadap variabel terikat.

\section{Uji Parsial (Uji t)}

Uji t digunakan untuk menguji secara parsial masing-masing variabel. Hasil uji t dapat dilihat pada tabel coefficients pada kolom sig (significance). Jika probabilitas nilai t atau signifikansi $<5 \%$, maka dapat dikatakan bahwa terdapat pengaruh antara variabel bebas terhadap variabel terikat secara parsial, atau Ha diterima dan Ho ditolak. Namun, jika probabilitas nilai $t$ atau signifikansi $>5 \%$, maka dapat dikatakan bahwa tidak terdapat pengaruh yang signifikan antara masing-masing variabel bebas terhadap variabel terikat, atau Ha ditolak dan Ho diterima.

\section{Metode Analisis}

Metode analisis yang digunakan untuk menguji hipotesis yang telah dirumuskan adalah analisis regresi linear berganda dengan bantuan software IBM SPSS Statistics Versi 21. Berikut persamaan regresi linear berganda yang digunakan:

$$
\begin{aligned}
& \mathrm{Y} 1=\alpha+\beta 1 \text { ROA }+\beta 2 \text { DER }+\beta 3 \text { LTA }+\mathrm{e} \\
& \mathrm{Y} 2=\alpha+\beta 1 \text { ROA }+\beta 2 \text { DER }+\beta 3 \text { LTA }+\mathrm{e} \\
& t=\frac{\text { Path Sample 1-Path Sample 2 }}{\sqrt{S \cdot E^{2}} \text { Sample 1+S.E. }{ }^{2} \text { Sample 2 }}
\end{aligned}
$$

Keteranggan:

$\mathrm{Y}_{1} \quad=$ Harga Saham (sample perusahaan Manufaktur yang terdaftar di Bursa Efek Indonesia)

$\mathrm{Y}_{2}=$ Harga Saham (sample perusahaan Manufaktur yang terdaftar di Bursa Malaysia)

B1-3 = Koefisien Regresi

a $\quad=$ Konstanta

e $=$ Error

$\mathrm{t}=$ Perbedaan Pengaruh

S.E $=$ Standar Error

Path $=\beta$ atau Koefisien Regresi

HASIL DAN PEMBAHASAN

\section{Uji Normalitas}

Tabel 2

Uji Normalitas Perusahaan Manufaktur Indonesia One-Sampel Kolmogorov-Smirnov Test

\begin{tabular}{lr}
\hline Kolmogorov-Smirnov Z & 0,900 \\
\hline Asymp. Sig. (2-tailed) & 0,393 \\
\hline
\end{tabular}

Dari tabel 1 di atas dapat dilihat bahwa probabilitas Asymp.sig(2-tailed) variabel-variabel dalam sampel penelitian perusahaan manufaktur yang terdaftar di BEI adalah sebesar 0,393, sehingga dapat disimpulkan bahwa ketiga variabel pada sampel perusahaan manufaktur Indonesia adalah normal. 
Tabel 3

Uji Normalitas Perusahaan Manufaktur Malaysia

\begin{tabular}{lr}
\hline \multicolumn{2}{c}{ One-Sampel Kolmogorov-Smirnov Test } \\
\hline Kolmogorov-Smirnov $Z$ & 0,558 \\
\hline Asymp. Sig. (2-tailed) & 0,914 \\
\hline
\end{tabular}

Dari tabel 2 di atas dapat dilihat bahwa probabilitas Asymp.sig(2-tailed) variabel-variabel dalam sampel penelitian perusahaan manufaktur yang terdaftar di Bursa Malaysia adalah sebesar 0,914, sehingga dapat disimpulkan bahwa ketiga variabel pada sampel perusahaan manufaktur Malaysia adalah normal.

\section{Uji Multikolinearitas}

Tabel 4.

Uji Multikolinearitas Perusahaan Manufaktur Indonesia

\begin{tabular}{|c|c|c|c|c|}
\hline \multirow{2}{*}{\multicolumn{2}{|c|}{ Model }} & \multicolumn{2}{|c|}{$\begin{array}{l}\text { Collinearity } \\
\text { Statistics }\end{array}$} & \multirow[t]{2}{*}{ Keterangan } \\
\hline & & Tolerance & VIF & \\
\hline \multirow{4}{*}{1} & (Constant) & & & \\
\hline & $\mathrm{ROA}$ & 0,993 & 1,007 & Tidak terjadi multikolinearitas \\
\hline & DER & 0,885 & 1,130 & Tidak terjadi multikolinearitas \\
\hline & LTA & 0,891 & 1,122 & Tidak terjadi multikolinearitas \\
\hline
\end{tabular}

Berdasarkan tabel 4 besarnya VIF yang dimiliki variabel ROA, DER, dan LTA dari sampel penelitian perusahaan manufaktur yang terdaftar di Bursa Efek Indonesia secara berturutturut adalah 1,$007 ; 1,130 ; 1,122$. Ketika variabel tersebut memiliki nilai VIF yang lebih kecil dari $10(\mathrm{VIF}<10)$, dapat dikatakan bahwa tidak terdapat gejala multikolinearitas diantara variabel independen dalam penelitian ini. Hal ini juga dibuktikan dengan nilai tolerance masing-masing variabel tersebut secara berturut-turut adalah sebesar 0,993; 0,885; dan 0,891. Ketiga nilai tersebut lebih besar dari 0,10 (tolerance $>0,10$ ) yang dapat dikatakan tidak terjadi multikolinearitas diantara varibel independen dalam model regresi ini.

Tabel 5

Uji Multikolinearitas Perusahaan Manufaktur Malaysia

\begin{tabular}{|c|c|c|c|c|}
\hline \multicolumn{2}{|c|}{ Model } & \multicolumn{2}{|c|}{$\begin{array}{c}\text { Collinearity } \\
\text { Statistics }\end{array}$} & \multirow[t]{2}{*}{ Tidak Terjadi Multikolinearitas } \\
\hline \multirow{4}{*}{1} & (Constant) & Tolerance & VIF & \\
\hline & $\mathrm{ROA}$ & 0,853 & 1,173 & Tidak terjadi multikolinearitas \\
\hline & DER & 0,716 & 1,397 & Tidak terjadi multikolinearitas \\
\hline & LTA & 0,766 & 1,305 & Tidak terjadi multikolinearitas \\
\hline
\end{tabular}

Berdasarkan tabel 5 besarnya VIF yang dimiliki variabel ROA, DER, dan LTA dari sampel penelitian perusahaan manufaktur yang terdaftar di Bursa Efek Malaysia secara berturutturut adalah 1,$173 ; 1,397$; dan 1,305. Ketika variabel tersebut memiliki nilai VIF yang lebih kecil dari $10(\mathrm{VIF}<10)$, sehingga dapat dikatakan bahwa tidak terdapat gejala multikolinearitas diantara variabel independen dalam penelitian ini. Hal ini juga dibuktikan dengan nilai tolerance masingmasing variabel tersebut secara berturut-turut adalah sebesar 0,$853 ; 0,716$; dan 0,766. Ketiga nilai tersebut lebih besar dari 0,10 (tolerance $>0,10$ ) yang dapat dikatakan tidak terjadi multikolinearitas diantara varibel independen dalam model regresi ini. 


\section{Uji Heteroskedasitas}

Gambar 1 Grafik Scatterpplot Perusahaan Manufaktur yang terdafar di Bursa Efek Indonesia

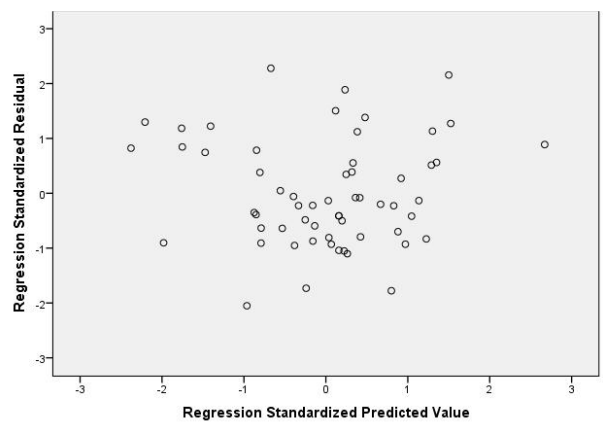

Gambar 2 Grafik Scatterpplot Perusahaan Manufaktur yang terdafar di Bursa Malaysia

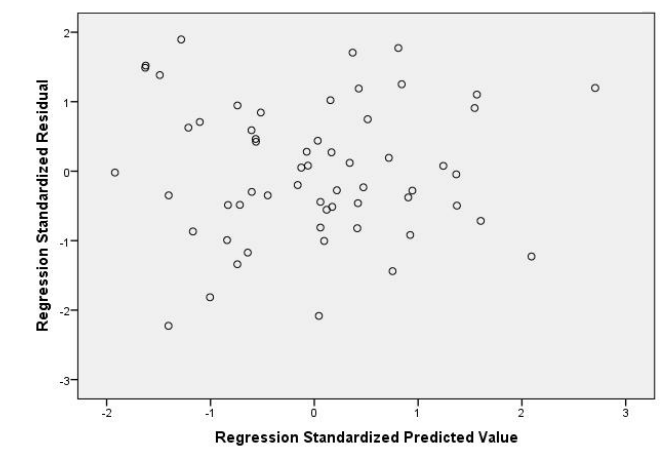

Gambar 1 dan Gambar 2 menunjukan titik menyebar secara acak dan tidak membentuk pola tertentu. Posisi titik-titik ini tersebar diatas dan dibawah angka 0 (nol) pada sumbu Y. Hal ini menunjukan bahwa tidak terjadi heteroskedesitas dalam model regesi ini hingga model regresi ini layak untuk digunakan sebagai data menguji pengaruh Return On Asset (ROA), Debt to Equity (DER) dan Ukuran Perusahaan (LTA) pada sampel penelitian perusahaan manufaktur yang terdaftar di Bursa Efek Indonesia dan bursa Malaysia. Dengan terpenuhinya seluruh asumsi klasik regresi di atas, maka dapat dikatakan model regresi linear berganda yang digunakan dalam penelitian ini sudah layak dan dapat dilanjutkan pada analisis selanjutnya, yaitu pengujian hipotesis yang mengunakan analisis regresi berganda.

\section{Analisis Regresi Berganda}

Tabel 6

Hasil Koefisien Regresi Berganda Perusahaan Manufaktur Indonesia

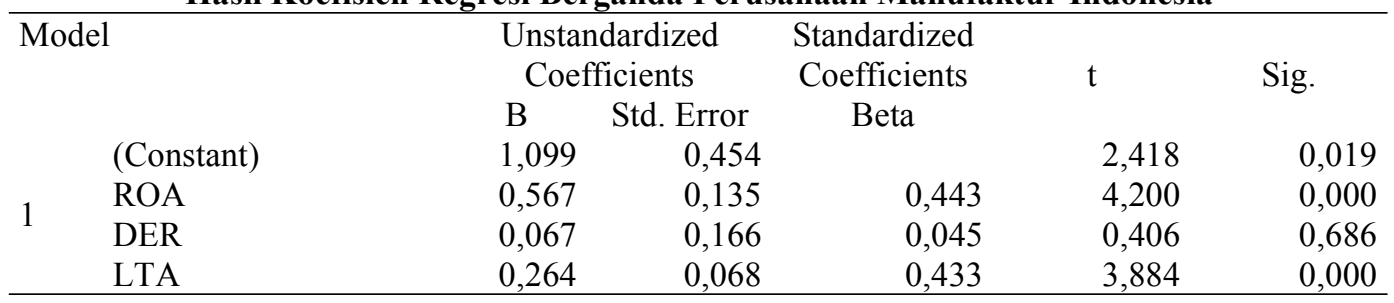

$\mathrm{Y}=1,099+0,567 \mathrm{ROA}+0,067$ DER + 0,264 LTA + 0,454. Model tersebut dapat di interprestasikan sebaga berikut: a) Konstanta memiliki koefisien sebesar 1,099. Hal tersebut menandakan bahwa jika ROA, DER, LTA tidak ada, maka harga saham menjadi sebesar 1,099; b) Return On Assets memiliki koefisien sebesar 0,567. Hal tersebut menandakan bahwa jika ROA naik sebesar 1 maka harga saham akan naik sebesar 0,567 dengan keadaan DER dan LTA tidak megalami perubahan; c) Debt to Equity Ratio memiliki koefisien sebesar 0,264. Hal tersebut menandakan bahwa jika DER naik sebesar 1 maka harga saham akan naik sebesar 0,264 dengan keadaan ROA dan LTA tetap tidak megalami perubahan; d) Ukuran Perusahaan yaitu memiliki koefisien sebesar 0,264. Hal tersebut menandakan bahwa jika ukuran perusahaan naik sebesar 1 maka harga saham akan naik sebesar 0,264 dengan keadaan ROA dan DER tidak megalami perubahan. 
Tabel 7

Hasil Koefisien Regresi Perusahaan Manufaktur Malaysia

\begin{tabular}{|c|c|c|c|c|c|c|}
\hline \multirow[t]{2}{*}{ Model } & & \multicolumn{2}{|c|}{ Unstandardized Coefficients } & Standardized & $\mathrm{t}$ & Sig. \\
\hline & & $\mathrm{B}$ & Std. Error & Beta & & \\
\hline \multirow{4}{*}{1} & (Constant) & $-1,384$ & 0,199 & & $-6,959$ & 0,000 \\
\hline & ROA & 0,411 & 0,079 & 0,462 & 5,215 & 0,000 \\
\hline & DER & $-0,015$ & 0,125 & $0-, 012$ & $-0,124$ & 0,902 \\
\hline & LTA & 0,456 & 0,072 & 0,596 & 6,372 & 0,000 \\
\hline
\end{tabular}

$\mathrm{Y}_{2}=-1,384+0,411$ ROA - 0,015 DER + 0,456 LTA+ 0,199. Model tersebut dapat di interprestasikan sebaga berikut: a) Konstanta memiliki koefisien sebesar memiliki koefisien sebesar -1,384. Hal tersebut menandakan bahwa jika ROA, DER, LTA tidak ada, maka harga saham menjadi sebesar -1,384; b) Return On Assets yaitu memiliki koefisien sebesar 0,411. Hal tersebut menandakan bahwa jika ROA naik sebesar 1 maka harga saham akan naik sebesar 0,411 dengan keadaan DER dan LTA tidak megalami perubahan; c) Debt to Equity Ratio memiliki koefisien sebesar -0,015 jika DER naik sebesar 1 maka harga saham akan turun sebesar 0,015 dengan keadaan ROA dan DER tidak mengalami perubahan; d) Ukuran Perusahaan yaitu memiliki koefisien sebesar 0,456. Hal tersebut menandakan bahwa jika ukuran perusahaan naik sebesar 1 maka harga saham akan naik sebesar 0,456 dengan keadaan dengan keadaan ROA dan DER tidak megalami perubahan.

\section{Uji Hipotesis}

Uji Koefisien Determinasi $\left(\mathbf{R}^{2}\right)$

Tabel 8

Hasil Uji R² Perusahaan Manufaktur Indonensia.

\begin{tabular}{llccc}
\hline \multicolumn{4}{c}{ Model Summary $^{\mathrm{b}}$} \\
\hline Model & $\mathrm{R}$ & $\mathrm{R}$ Square & $\begin{array}{c}\text { Adjusted R } \\
\text { Square }\end{array}$ & $\begin{array}{c}\text { Std. Error of the } \\
\text { Estimate }\end{array}$
\end{tabular}

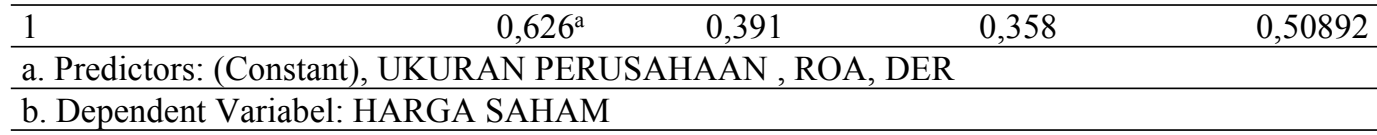

Berdasarkan ouput pada tabel 8 diperoleh nilai Adjusted $R$ Square sebesar 0,358 atau sama dengan 35,8\%. Nilai tersebut menunjukan bahwa sebesar 35,8\% harga saham dipengaruhi oleh variabel ROA, DER, dan LTA. Sedangkan 64,2\% lainya dipengaruhi oleh variabel-variabel lain yang tidak dimasukkan dalam penelitian ini.

Tabel 9

Hasil Uji $\mathbf{R}^{2}$ Perusahaan Manufaktur Malaysia

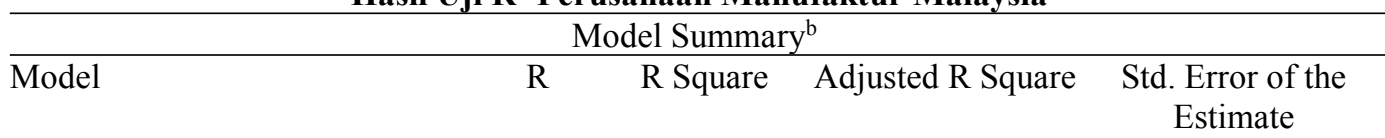

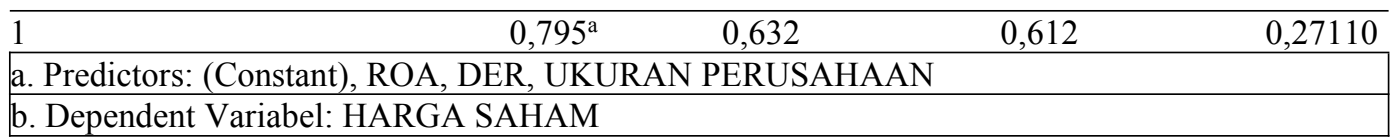

Berdasarkan ouput pada tabel 9 diperoleh nilai Adjusted $R$ Square sebesar 0,612 atau sama dengan $61,2 \%$. Nilai tersebut menunjukan bahwa sebesar $61,2 \%$ harga saham dipengaruhi oleh variabel harga saham dipengaruhi oleh variabel ROA, DER dan LTA. Sedangkan 39,8\% lainya dipengaruhi oleh variabel-variabel lain yang tidak dimasukkan dalam penelitian ini 
Uji Simultan (Uji F)

Tabel 10

Hasil Uji Simultan Perusahaan Manufaktur Indonesia

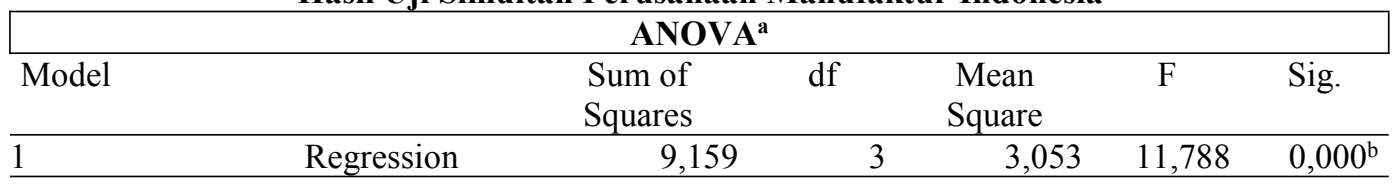

Berdasarkan pada tabel 10 diatas, hasil uji simultan (uji F) dapat dilihat bahwa nilai Sig.

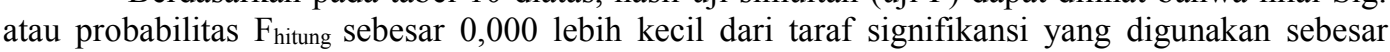
0,05 hal ini menandakan bahwa model regresi layak untuk digunakan pada penelitian berikutnya

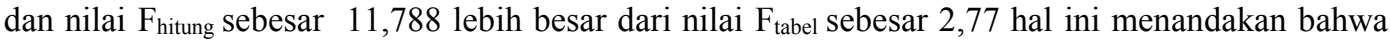
seluruh variabel independen secara bersamaan memengaruhi variabel dependen.

Tabel 11

Hasil Uji Simultan Perusahaan Manufaktur Malaysia

\begin{tabular}{|c|c|c|c|c|c|c|}
\hline \multicolumn{7}{|c|}{ ANOVA $^{a}$} \\
\hline Model & & Sum of Squares & If & $\begin{array}{l}\text { Mean } \\
\text { Square }\end{array}$ & $\mathrm{F}$ & Sig. \\
\hline 1 & Regression & 6,936 & 3 & 2,312 & 31,460 & $0,000^{\mathrm{b}}$ \\
\hline
\end{tabular}

Berdasarkan pada tabel 11 diatas, hasil uji simultan (uji F) dapat dilihat bahwa nilai Sig. atau probabilitas $F_{\text {hitung }}$ sebesar 0,000 lebih kecil dari taraf sigfikansi yang digunakan sebesar 0,05 hal ini menandakan bahwa model regresi layak untuk digunakan pada penelitian berikutnya. dan

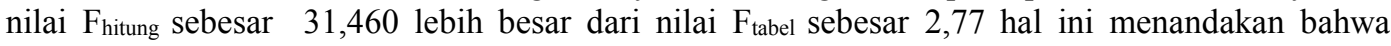
seluruh variabel independen secara bersamaan memengaruhi variabel dependen.

Uji Parsial (Uji t)

Tabel 12

Hasil Uji Parsial Perusahaan Manufaktur Indonesia

\begin{tabular}{llrr}
\hline Model & & $\mathrm{t}$ & Sig. \\
1 & (Constant) & 2,418 & 0,019 \\
& ROA & 4,200 & 0,000 \\
DER & & 0,406 & 0,686 \\
& LTA & 3,884 & \\
& & & 0,000 \\
\hline
\end{tabular}

Dengan melihat hasil uji tabel 12 di atas, maka kesimpulan yang dapat diambil adalah sebagai berikut:

Hipotesis pertama menyatakan bahwa Return On Assets berpengaruh terhadap harga saham di Indonesia.

Hasil pengujian statistik menunjukan bahwa signifikansi t sebesar 0,000 lebih kecil dari $0,05(0,000<0,05)$. Nilai thitung lebih besar dari $t_{\text {tabel }}\left\{t_{\text {hitung }} 4,200>t_{\text {tabel }} 2,004(a=0,05 d a n d f=55)\right\}$, dengan demikian $\mathrm{H}_{0}$ ditolak yang menandakan bahwa Return On Assets berpengaruh terhadap harga saham di Indonesia dan memiliki pengaruh yang positif. Jika Return On Assets naik maka harga saham juga akan naik.

Hipotesis keempat menyatakan Debt to Equity berpengaruh terhadap harga saham di Indonesia.

Hasil pengujian statistik menunjukan bahwa signifikansi t sebesar 0,686 lebih besar dari $0,05(0,686>0,05)$. Nilai $t_{\text {hitung }}$ lebih besar dari $t_{\text {tabel }}\left\{t_{\text {hitung }}-0,406<t_{\text {tabel }} 2,004(a=0,05 \mathrm{dan} d f=55)\right\}$, dengan demikian $\mathrm{H}_{0}$ diterima yang menandakan bahwa Debt to Equity Ratio tidak berpengaruh terhadap harga saham 


\section{Hipotesis ketujuh menyatakan Ukuran Perusahaan berpengaruh terhadap harga saham di Indonesia.}

Hasil pengujian statistik menunjukan bahwa signifikansi t sebesar 0,000 lebih kecil dari $0,05(0,000<0,05)$. Nilai thitung lebih besar dari tabel $\left\{t_{\text {hitung }} 3,884>t_{\text {tabel }} 2,004(\mathrm{a}=0,05\right.$ dan $\mathrm{df}=55)\}$, dengan demikian $\mathrm{H}_{0}$ ditolak yang menandakan bahwa ukuran perusahaan berpengaruh terhadap harga saham di Indonesia dan memiliki pengaruh yang positif.

Tabel 13

Hasil Uji Persial Perusahaan Manufaktur Malaysia

\begin{tabular}{|c|c|c|c|}
\hline & Model & $\mathrm{t}$ & Sig. \\
\hline \multirow{4}{*}{1} & (Constant) & $-6,959$ & 0,000 \\
\hline & ROA & 5,215 & 0,000 \\
\hline & DER & $-0,124$ & 0,902 \\
\hline & LTA & 6,372 & 0,000 \\
\hline
\end{tabular}

Dengan melihat hasil uji tabel 13 di atas, maka kesimpulan yang dapat diambil adalah sebagai berikut:

\section{Hipotesis Kedua menyatakan bahwa Return On Assets berpengaruh terhadap harga saham di Malaysia.}

Hasil pengujian statistik menunjukan bahwa signifikansi t sebesar 0,000 lebih kecil dari

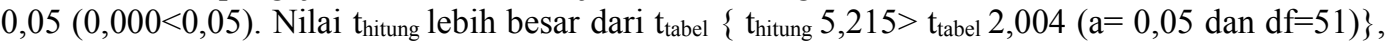
dengan demikian $\mathrm{H}_{0}$ ditolak yang menandakan bahwa Return On Assets berpengaruh terhadap harga saham di Malaysia dan memiliki pengaruh yang positif. Jika Return On Assets naik maka harga saham juga akan naik.

\section{Hipotesis kelima menyatakan Debt to Equity berpengaruh terhadap harga saham di Malaysia .}

Hasil pengujian statistik menunjukan bahwa signifikansi t sebesar 0,902 lebih besar dari $0,05(0,902>0,05)$. Nilai $t_{\text {hitung }}$ lebih kecil dari $t_{\text {tabel }}\left\{t_{\text {hitung }}-0,124<t_{\text {tabel }} 2,004(\mathrm{a}=0,05 \mathrm{dan} \mathrm{df}=55)\right\}$, dengan demikian $\mathrm{H}_{0}$ diterima dan $\mathrm{H}_{5}$ ditolak yang menandakan bahwa Debt to Equity tidak berpengaruh terhadap harga saham di Malaysia.

\section{Hipotesis kedelapan menyatakan Ukuran Perusahaan berpengaruh terhadap harga saham di Malaysia. \\ Hasil pengujian statistik menunjukan bahwa signifikansi t sebesar 0,000 lebih kecil dari} $0,05(0,000<0,05)$. Nilai $t_{\text {hitung }}$ lebih besar dari $t_{\text {tabel }}\left\{t_{\text {hitung }} 6,372>t_{\text {tabel }} 2,004(a=0,05\right.$ dan $\mathrm{df}=55)\}$, dengan demikian $\mathrm{H}_{0}$ ditolak yang menandakan bahwa ukuran perusahaan berpengaruh terhadap harga saham di Malaysia dan memiliki pengaruh yang positif.

Pada penelitian ini menggunakan uji Smith-Satterthwait sebagai alat uji untuk membandingkan signifikansi koefisien regresi variabel bebas sampel perusahaan manufaktur yang terdaftar di Bursa efek Indonesia dengan sampel perusahaan manufaktur yang terdaftar di bursa Malaysia. Variabel bebas yang diuji dengan alat uji ini adalah variabel bebas dari sampel perusahaan manufaktur yang terdaftar di Bursa Efek Indonesia dan sampel perusahan manufaktur yang terdaftar di bursa Malaysia yang sama-sama berpengaruh signifikan dan sama-sama tidak signifikan terhadap variabel terikat (Harga Saham) bedasarkan uji t yang telah dilakukan sebelumnya. Berdasarkan hal tersebut, variabel Return On Asset (ROA), Debt to Equity (DER), dan ukuran perusahaan (LTA) merupakan variabel yang dapat diuji dengan alat uji ini karena memiliki pengaruh signifikan terhadap variabel terikat yaitu harga saham perusahaan manufaktur yang terdaftar di Bursa Efek Indonesia dan Bursa Malaysia. Adapun rumus uji Smith-Satterthwait yang digunakan dalam penelitian ini adalah sebagai berikut: 


$$
t=\frac{\text { Path Sample } 1-\text { Path Sample } 2}{\sqrt{\text { S.E }} \text { Sample } 1+\text { S.E. }{ }^{2} \text { Sample 2 }}
$$

Keterangan:

$t \quad=$ Perbedaan Pengaruh

S.E $=$ Standar Error

Path $\quad=\beta$ atau Koefisien Regresi

Berdasarkan data hasil uji $\mathrm{t}$ yang telah dilakukan sebelumya, maka hasil SmithSatterthwait dengan mengunakan data tersebut adalah sebagai berikut:

$$
\begin{gathered}
t(R O A)=\frac{0,567-0,411}{\sqrt{0,135^{2}}+0,018^{2}} \\
t(R O A)=\frac{0,156}{\sqrt{0,018549}} \\
t(R O A)=1,15 \\
t(D E R)=\frac{0,67-(-0,015)}{\sqrt{0,166^{2}}+0,125^{2}} \quad t(\text { ROA })=\frac{0,685}{\sqrt{0,2078}} \\
t(\text { ROA })=3,30 \\
t(\text { Ukuraan Perusahaan })=\frac{0,264-0,456}{\sqrt{0,068^{2}}+0,72^{2}} \\
t(\text { Ukuran Perusahaan })=\frac{-0,192}{\sqrt{0,723204}} \\
t(\text { Ukuran Perushaan })=-0,27
\end{gathered}
$$

\section{Pembahasan}

Pembahasan penelitian menyangkut pada penelitian yaitu :

1. ROA berpengaruh terhadap harga saham di Indonesia. Hasil pengujian statistik menunjukan bahwa signifikansi t sebesar 0,000 lebih kecil dari $0,05(0,000<0,05)$. Nilai thitung lebih besar dari $t_{\text {tabel }}\left\{t_{\text {hitung }} 4,200>\mathrm{t}_{\text {tabel }} 2,004(\mathrm{a}=0,05 \mathrm{dan} \mathrm{df}=55)\right\}$. Menandakan bahwa ROA berpengaruh terhadap harga saham di Indonesia dan memiliki pengaruh yang positif. Jika $R O A$ naik maka harga saham juga akan naik.

2. ROA berpengaruh terhadap harga saham di Malaysia. Hasil pengujian statistik menunjukan bahwa signifikansi t sebesar 0,000 lebih kecil dari $0,05(0,000<0,05)$. Nilai thitung lebih besar dari $t_{\text {tabel }}\left\{t_{\text {hitung }} 5,215>t_{\text {tabel }} 2,004(a=0,05\right.$ dan $\left.\mathrm{df}=51)\right\}$. Menandakan bahwa ROA berpengaruh terhadap harga saham di Malaysia dan memiliki pengaruh yang positif. Jika ROA naik maka harga saham juga akan naik.

3. Berdasarkan uji Smith-Satterthwait didapatkan hasil thitung sebesar 1,15. Nilai ini lebih kecil dibandingkan 1,96 ( thitung $<\mathrm{t}_{\text {tabel}}$ ). Oleh karena itu, dapat diambil kesimpulan bahwa tidak terdapat perbedaan pengaruh yang signifikan antara pengaruh antara variabel ROA terhadap harga saham pada perusahaan manufaktur yang terdaftar di Bursa Efek Indonesia dan perusahaan manufaktur yang terdaftar di Bursa Malaysia. 
4. Hasil pengujian statistik menunjukan bahwa signifikansi t sebesar 0,686 lebih besar dari 0,05 $(0,686>0,05)$. Nilai thitung lebih besar dari tabel $\left\{\right.$ thitung $\left.-0,406<t_{\text {tabel }} 2,004(\mathrm{a}=0,05 \mathrm{dan} \mathrm{df}=55)\right\}$. menandakan bahwa DER tidak berpengaruh terhadap harga saham di Indonesia.

5. Hasil pengujian statistik menunjukan bahwa signifikansi t sebesar 0,902 lebih besar dari 0,05 $(0,902>0,05)$. Nilai $t_{\text {hitung }}$ lebih kecil dari $t_{\text {tabel }}\left\{\mathrm{t}_{\text {hitung }}-0,124<\mathrm{t}_{\text {tabel }} 2,004(\mathrm{a}=0,05 \mathrm{dan} \mathrm{df}=55\right.$ menandakan bahwa DER tidak berpengaruh terhadap harga saham di Malaysia.

6. Berdasarkan uji Smith-Satterthwait didapatkan hasil thitung sebesar 3,30 Nilai ini lebih besar dibandingkan 1,96 ( $\mathrm{t}_{\text {hitung }}>\mathrm{t}_{\text {tabel }}$. Oleh karena itu, dapat diambil kesimpulan bahwa terdapat perbedaan pengaruh yang signifikan antara pengaruh antara variabel DER terhadap harga saham pada perusahaan manufaktur yang terdaftar di Bursa Efek Indonesia dan perusahaan manufaktur yang terdaftar di Bursa Malaysia.

7. Hasil pengujian statistik menunjukan bahwa signifikansi t sebesar 0,000 lebih kecil dari 0,05 $(0,000<0,05)$. Nilai thitung lebih besar dari tabel $\left\{\mathrm{t}_{\text {hitung }} 3,884>\mathrm{t}_{\text {tabel }} 2,004(\mathrm{a}=0,05 \mathrm{dan} \mathrm{df}=55)\right\}$. Menandakan bahwa Ukuran Perusahaan berpengaruh terhadap harga saham di Indonesia dan memiliki pengaruh yang positif.

8. Pengujian s statistik menunjukan bahwa signifikansi t sebesar 0,000 lebih kecil dari 0,05 $(0,000<0,05)$. Nilai $t_{\text {hitung }}$ lebih besar dari $t_{\text {tabel }}\left\{\mathrm{t}_{\text {hitung }} 6,372>\mathrm{t}_{\text {tabel }} 2,004(\mathrm{a}=0,05 \mathrm{dan} \mathrm{df}=55)\right\}$ menandakan bahwa Ukuran Perusahaan berpengaruh terhadap harga saham di Malaysia dan memiliki pengaruh yang positif.

9. Berdasarkan uji Smith-Satterthwait yang lebih dilakukan sebelumnya, didapatkan hasil thitung sebesar-0,27. Nilai ini lebih kecil dibandingkan 1,96 ( $\left.\mathrm{t}_{\text {hitung }}<\mathrm{t}_{\text {tabel }}\right)$. Oleh karena itu, dapat diambil kesimpulan bahwa terdapat tidak ada perbedaan pengaruh yang signifikan antara pengaruh antara variabel ukuran perusahaan terhadap harga saham pada perusahaan manufaktur yang terdaftar di Bursa Efek Indonesia dan perusahaan manufaktur yang terdaftar di Bursa Malaysia.

\section{KESIMPULAN DAN SARAN}

\section{Kesimpulan}

Berdasarkan hasil analisis data dan pembahasan maka dapat disimpulkan: 1) Return On Asset berpengaruh terhadap harga saham di Indonesia dan memiliki pengaruh yang positif. 2) ROA berpengaruh terhadap harga saham di Malaysia dan memiliki pengaruh yang positif. 3) Bahwa tidak terdapat perbedaan pengaruh yang signifikan antara hasil variabel ROA pada sampel perusahaan manufaktur yang terdaftar di Bursa Efek Indonesia dan bursa Efek Malaysia. 4) Debt to Equity Ratio tidak berpengaruh terhadap harga saham Indonesia. 5) Debt to Equity Ratio tidak berpengaruh terhadap harga saham Malaysia. 6) Bahwa terdapat perbedaan pengaruh yang signifikan antara pengaruh antara variabel Debt to Equity (DER) terhadap harga saham pada perusahaan manufaktur yang terdaftar di Bursa Efek Indonesia dan perusahaan manufaktur yang terdaftar di Bursa Malaysia. 7) Ukuran perusahaan berpengaruh positif terhadap harga saham Indonesia. 8) Ukuran perusahaan berpengaruh positif terhadap harga saham Malaysia. 9) Bahwa tidak terdapat perbedaan pengaruh variabel ukuran perusahaan terhadap harga saham di Indonesia dan Malaysia, para invetor sama-sama beranggapan bahwa semakin besar ukuran suatu perusahaan maka semakin tinggi harga saham tersebut.

Saran

Penelitian ini memberikan beberapa saran: 1) Untuk penelitian yang akan datang disarankan menggunakan lebih banyak data dari segi waktu dari beberapa periode tahun dan penyempitan data agar data tersebut lebih akurat, serta menambahkan beberapa variabel independen agar informasi dalam variabel tersebut memiliki informasi yang dibutuhkan bagi variabel dependen yaitu harga saham di Indonesia dan Malaysia. 2) Untuk para investor dan calon investor disarankan untuk mengutamakan saham perusahaan yang memiliki nilai $R O A$ dan Ukuran Perusahaan yang besar karena berdasarkan penelitian ini, variabel $R O A$ dan Ukuran Perusahaan mempunyai pengaruh yang positif terhadap harga saham. 3) Untuk perusahaan disarankan untuk memaksimalkan potensi-potensi yang dimiliki perusahaan agar dapat meningkatkan $R O A$ dan ukuran perusahan, sehingga saham perusahaan semakin diminati oleh para investor dan calon investor di Indonesia dan Malaysia 


\section{DAFTAR PUSTAKA}

B. Mahardika dan A. Roosmawarni. (2016). Analisi Karakteristik Perusahaan yang Mempengauhi Nilai Perusahaan Pada Perusahaan Manufaktur yang Terdaftar di Bursa Efek Indonesia (BEI) Tahun 2010-2014. Jurnal Balance. Volume 13.

Darmadji, Tjiptono dan Hendy M. Fakhruddin. (2012). Pasar Modal di Indonesia.Edisi Ketiga. Jakarta: Salemba Empat

Fahmi, Irham. (2012). Analisis Laporan Keuangan. Cetakan Kedua. Bandung: Alfabeta

Fakhruddin, Hendy M. (2008). Istilah Pasar Modal A-Z. Jakarta:Elex Media Komputindo.

Fahriyah, Siti. (2015). Pengaruh Total Debt Equity Ratio, Return On Equity,Earning Per Share dan Price Earning Ratio terhadap Harga Saham. Jurnal Ilmiah Mahasiswa FEB Universitas Brawijaya. Volume 3.

Firmasnyah, E.A (2017). Perbandingan antara Bursa Efek Indonesia danMalaysia. Jurnal Inspirasi Bisnis dan Manajemen. Volume 1. Hal 1-10

Gitaya, Nindya. (2014). Pengaruh Earning Per Share, Return On Equity, PriceEarning Ratio, dan Return On Asset terhadap Harga Saham (Studi Pada Perusahaan Manufaktur yang Terdaftar di Bursa Efek Indonesia). Jurnal Ilmiah Mahasiswa FEB Universitas Brawijaya. Volume 3.

Ghozali, Imam. (2012). Aplikasi Analisis Multivariate dengan Program IBM SPSS 20. Semarang: UNDIP

Harahap, Sofyan Syafri. 2011. Analisis Kritis Atas Laporan Keuangan.Raja Grindo Persada, Jakarta.

Harahap, Sofyan Syafri. 2013. Analisis Kritis Atas Laporan Keuangan Edisi 11. Rajawali Pers, Jakarta.

Jakaria, Yaya. (2015). Mengolah Data Penelitian Kuantitatif dengan SPSS. Bandung: Alfabeta

Jogiyanto, Hartono. (2015). Teori Portofolio dan Analisis Investasi. Edisi Kesepuluh. Yogyakarta: BPFE.

Jogiyanto, Hartono. (2013). Teori Portofolio dan Analisis Investasi. Edisi Kedelapan. Yogyakarta: BPFE

Kasmir. (2012). Analisis Laporan Keuangan. Jakarta: PT. Raja Grafindo Persada

Meythi, Tan Kwang En dan Linda Rusli. (2011). Pengaruh Likuiditas dan Profitabilitas terhadap Harga Saham Perusahaan Manufaktur yang Terdaftar di Bursa Efek Indonesia. Jurnal Bisnis Manajemen dan Ekonomi. Volume 10. hal: 2671-2684.

Purnama, Dendi. (2018). Analisi Karakteristik Perusahaan dan Environmental Performance Terhadap Environmental Disclosure. JRKA Volume 4. Hal: 1 - 14

Pratama, Aditya dan Teguh Erawati. (2014). Pengaruh, Current Ratio, Debt to Equity Ratio, Return On Equity Net Profit Margin dan Earning Per Share Terhadap Harga Saham (Studi Kasus Pada Perusahaan Manufaktur yang Terdaftar di Bursa Efek Indonesia Periode 2008-2011). Jurnal Akuntasi. Volume 2. hal: 1-10.

Prawironegoro dan Purwanti. (2008). Akuntansi Manajemen. Edisi Kedua. Jakarta: Mitra Wacana Media. 
Riyanto, Bambang. (2010). Dasar-dasar Pembelanjaan Perusahaan. Edisi Keempat. Cetakan Kesepuluh. Yogyakarta: BPFE

R.k. Kumaidi dan N. Asandimitra. (2017). Pengaruh ROA, ROE, DER, DPR, Dan LDR Terhadap Harga Saham Sektor Perbankan BEI Periode 2011-2016. Jurnal Ilmu Manajemen Volume 5.

Rusdin. (2009). Pasar Modal. Bandung: Alfabeta.

Subhan, A.M. (2016). Pengaruh Net Profit Margin, Return On Equity dan Earning Per Share terhadap Harga Saham Perusahaan Industri Barang Konsumsi yang Tercatat di Bursa Efek Indonesia. Jurnal Profita Edisi 3.

Subhair, Faisal. (2013). Karakteristik Perusahaan dan Industri Terhadap Pengungkapan Dalam Laporan Keuangan Pada Perusahaan Manufktur yang Go Publik. Jurnal Emba Vol.1. Hal: 763-774.

Setyorini, Maria M Minarsih, dan Andi Tri Haryono Pengaruh Return On Assets(ROA), Return On Equity (ROE), dan Earning Per Share (EPS) terhadap Harga saham Perusahaan Real Estate di Bursa Efek Indonesia. Journal Of Management, Volume 2 No.2.

Tandelilin, Eduardus. (2010). Portofolio dan Investasi Teori dan Aplikasi. Edisi Pertama. Yogyakarta.

Umar, Husein. (2011). Metode Penelitian untuk Skripsi dan Tesis Bisnis. Edisi Kedua. Jakarta: Rajawali Pers

Wangarry, Andreas R., Agus T. Poputra dan Treesje Runtu. (2015). Pengaruh Tingkat Return On Investment (ROI), Net Profit Margin (NPM), dan Debt to Equity Ratio (DER) terhadap Harga Saham Perbankan di Bursa Efek Indonesia (BEI). Jurnal EMBA. Volume 3. hal: 470-477.

Widoatmodjo, Sawidji. (2012). Cara Cepat Memulai Investasi Saham Panduan Bagi Pemula. Jakarta: Elex Media Komputindo. 